\title{
PENINGKATKAN KETERAMPILAN MOTORIK HALUS ANAK MELALUI KEGIATAN MENGANYAM DENGAN MENGGUNAKAN MEDIA SEDOTAN PADA ANAK KELOMPOK A DI PAUD AZ-ZAITUN GENTING TANAH TAHUN PEMBELAJARAN 2018/2019
}

\author{
Rusni \\ PG PAUD Universitas Widya Gama Mahakam Samarinda \\ rusnipauduwgm@gmail.com \\ Andi Aslindah \\ PG PAUD Universitas Widya Gama Mahakam Samarinda \\ aslindah.andirezky@yahoo.com
}

\begin{abstract}
Abstrack
The researcher conducted a classroom action research in Az-zaitun Genting Tanah preschool to improve students' fine motor skill through weaving. Fourteen students who age four to five years old (seven males and seven females) were involved as the research subjects. Moreover, in collecting data the researcher applied two cycles. The data was analyzed statistically in form of percentage. Having analyzed the data, there is found a significant increase on students' fine motor skill. At the first cycle, $44 \%$ students reached the passing grade and then increased into $80 \%$ in cycle 2 . Therefore, it can be concluded that learning through weaving is effective to improve students' fine motor skill, especially in Group A at Az-zaitun Genting Tanah Pre-school.
\end{abstract}

Key words: Fine Motor Skill, Straw Weaving 


\section{PENDAHULUAN}

Pendidikan anak usia dini adalah suatu upaya pembinaan yang ditujukan kepada anak sejak lahir sampai dengan usia enam tahun, yang dilakukan melalui pemberian rangsangan pendidikan untuk membantu pertumbuhan dan perkembangan jasmani dan rohani agar anak memiliki kesiapan dalam memasuki pendidikan lebih lanjut. Salah satu aspek perkembangan anak usia dini anak adalah perkembangan motorik. (Bambang Sujiono 2005: 110)

Memperoleh gerak dan pola gerakan yang dilakukan oleh anak merupakan proses perkembangan motorik yang baik (Widya and Mahakam 2017). Perkembangan motorik adalah proses seseorang anak belajar untuk terampil menggerakkan anggota tubuh, melatih ketangkasan, kecepatan, kekuatan, kelenturan, serta ketepatan koordinasi tangan dan mata, sedangkan pengertian motorik halus sendiri adalah pengorganisasian penggunaan sekelompok otot- otot kecil seperti jari-jemari dan tangan yang sering membutuhkan kecermatan dan koordinasi dengan tangan, keterampilan yang mencakup pemanfaatan menggunakan alat-alat untuk mengerjakan suatu objek. Program pengembangan keterampilan motorik anak usia dini seringkali terabaikan atau dilupakan oleh orangtua, pembimbing atau bahkan guru sendiri. Hal ini dikarenakan mereka belum memahami bahwa program pengembangan keterampilan motorik menjadi bagian yang tidak terpisahkan dalam kehidupan anak usia dini.

Berdasarkan pengamatan pada anak kelompok A PAUD Az-zaitun Genting Tanah menunjukan bahwa kemampuan motorik halus anak masihdikatakankurang berkembang dengan maksimal. Terlihat pada kegiatan salah satunya menganyam dimana terdapat beberapa anak yang masih kaku saat melakukannya menyebabkan hasil anyamannya cenderung tidak rapi serta dalam setiap kegiatan pembelajaran masih terdapat beberapa anak yang harus dibantu. Hal tersebut disebabkan karena media pembelajaran yang digunakan dalam mengasah keterampilan motorik halus jarang dilakukan misalnya dengan kegiatan menganyam tersebut. Perkembangan motorik yang baik merupakan proses memperoleh gerak dan pola gerakan yang dilakukan oleh anak (Widya and Mahakam 2017). Jadi, pengembangan motorik halus anak sangat penting sebab dengan mengembangkan kemampuan motorik halus anak mampu melatih otot-otot kecil seperti gerakan jari tangan, mampu mengkoordinasikan kecepatan tangan dengan mata, serta mampu mengendalikan emosi.

Maka dari itu, perlu dilakukannya kegiatan yang dapat meningkatkan kemampuan motorik halus anak, salah satunya dengan kegiatan menganyam menggunakan sedotan karena dengan 
adanya kegiatan atau praktek secara langsung diharapkan dapat menarik perhatian dan minat anak, dapat melatih gerakan koordinasi mata dan tangan, melatih ketelitian dan kesabaran anak, serta melatih anak untuk lebih kreatif.

\section{METODE PENELITIAN}

\section{Jenis Penelitian}

Jenis penelitian yang akan dilakukan oleh peneliti adalah penelitian tindakankelas/PTK (classroom action research). PTK adalah proses pengkajian masalah pembelajarandi dalam kelas melalui refleksi diri dalam upaya untuk memecahkan masalahdengan melakukan berbagai tindakan yang terencana dalam situasi nyataserta menganalisis setiap pengaruh dari perlakuan yang tujuannya untuk meningkatkan kemampuan motorik halus anak usia dini melaluikegiatan menganyam menggunakan media sedotan khususnya pada anak kelompok A di PAUD Az-zaitun Genting Tanah.

Penelitian ini menggunakan model spiral yang dikembangkan olehStephen Kemmis dan Robin Mc Taggart, dalampenelitian ini akan digunakan 2 siklus tindakan yang terdiri dari empatkomponen tindakan berupa perencanaan. Adapun tahap penelitian sebagai berikut :

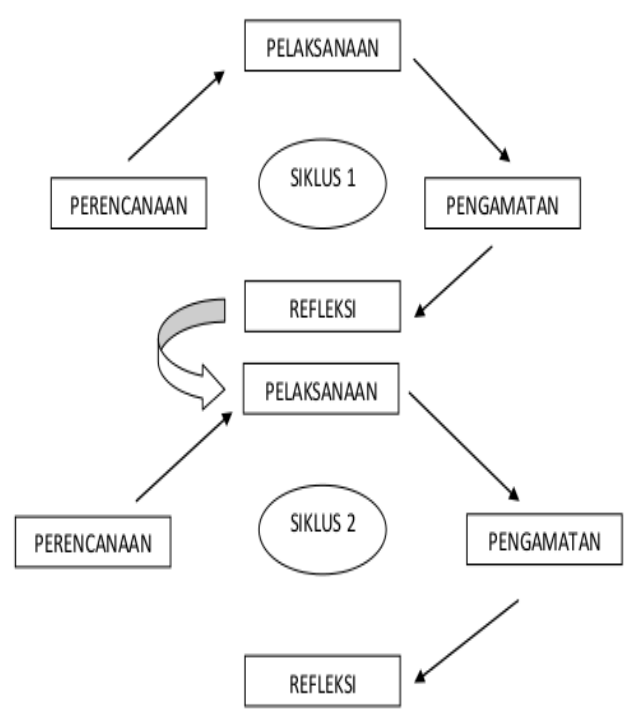

Gambar.1 siklus penelitian tindakan kelas (PTK) (Arikunto : 2016 :144)

Dalam penelitian ini langkah-langkah tindakan yang akan dilakukan adalah :

\section{Siklus}

\section{Perencanaan}

Dalam tahap ini kegiatan yang dilaksanakan guru adalah :

1) Membuat Rencana Pelaksanaan Pembelajaran Harian (RPPH)

2) Membuat Rencana Pelaksanaan Pembelajaran Mingguan (RPPM)

3) Menyediakan media pembelajaran kegiatan menganyam yaitu sedotan, gunting, lem dan sebagainya

4) Menyusun dan membuat lembar observasi siswa

\section{Pelaksanaan}

Tindakan ini dilakukan dengan menggunakan panduan perencanaan yang telah dibuat dan dalam pelaksanaanya bersifat fleksibel dan terbuka terhadap perubahan-perubahan selama proses 
pembelajaran berlangsung. Adapun pelaksaannya meliputi :

1) Kegiatan awal

a. Anak disiapkan dalam barisan, guru menyapa memberi salam dan mengajak berdoa sebelum memulai aktivitas.

b. Anak aktif ikut bernyanyi sambil menari mengikuti irama lagu

c. Mejelaskan nama hari, bulan dan tahun

d. Menerangkan tema dan tujuan pelajaran

e. Anak aktif menyimak dan mendengarkan penjelasan dari Guru

2) Kegiatan Inti

a. Pada kegiatan ini guru menjelaskan secara rinci menyampaikan materi yang berkaitan dengan menganyam, langkah-langkah menganyam, bentuk/ hasil anyaman dan sebagainya

b. Anak - anak mempraktikan sendiri langkah- langkah menganyam dengan menggunakan sedotan.

3) Istirahat/makan

a. Bermain diluar ruangan

b. Cuci tangan sebelum dan sesudah makan

c. Berdoa sebelum dan sesudah makan.

4) Kegiatan Akhir
Anak diajak berdiskusi bersama untuk menilai hasil pekerjaan hari ini. Memberikan motivasi kepada anak yang masih kurang berhasil dan memberi reward kepada anak yang telah melaksanakan pekerjaan dengan baik, menyampaikan kegiatan yang akan dilakukan besok kemudian ditutup dengan meyampaikan beberapa pesan lalu salam dan berdoa.

\section{Observasi}

Observasi dilaksanakan selama proses pembelajaran di kelas berlangsung dengan menggunakan lembar observasi yang telah dibuat. Obervasi dilakukan untuk melihat proses kegiatan belajar mengajar secara langsung bagaimana partisipasi siswa pada saat proses pembelajaran berlangsung.

\section{Refleksi}

Refleksi adalah mengingat, merenungkan, mencermati, dan menganalisis kembali suatu kegiatan atau tindakan yang telah dilakukan sebagaimana yang telah dicatat dalam observasi (Asrori, 2009: 64). Refleksi bertujuan untuk mengevaluasi hasil tindakan yang telah dilakukan yaitu dengan cara melakukan penilaian terhadap proses yang terjadi, masalah yang muncul dan segala hal yang berkaitan dengan tindakan yang dilakukan. Setelah itu mencari jalan keluar terhadap masalah-masalah yang mungkin timbul sehingga dapat menentukan upaya perbaikan pada setian siklus berikutnya. 
Refleksi ini mencakup analisis, sintesis, dan penilaian terhadap hasil pengamatan atas tindakan yang dilakukan. Jika terdapat masalah dari proses refleksi maka dilakukan proses pengkajian ulang melalui siklus berikutnya (Suharjono, 2007: 18).

Hasil yang didapat dari hasil siklus pertama yaitu jika anak belum mampu melakukan kegiatan menganyam sesuai dengan aspek penilaian, maka pada siklus pertama ini akan dianalisis dan dipelajari. Dari hasil analisis tersebut selanjutnya diukur tingkat keberhasilan dan dicari solusi perbaikan untuk ditindaklanjuti pada siklus kedua.

\section{Subjek Penelitian}

Subjek penelitian ini adalah semua anak kelompok A PAUD Az-zaitun Genting Tanah, yang berjumlah 14 orang anak yang terdiri dari 7 anak laki-laki dan 7 anak perempuan. Penelitian tindakan kelas ini dilaksanakan di PAUD Az-zaitun Genting Tanah dan waktu pelaksanaanya yaitu semester ganjil tahun pembelajaran 2018/2019 .

\section{Metode Pengumpulan Data}

\section{Observasi}

Observasi atau pengamatan dilakukan oleh peneliti dengan cara melakukan pengamatan dan pencatatan mengenai pelaksanaan pembelajaran di kelas serta partisipasi yang ditujukan siswa pada saat proses kegiatan belajar mengajar berlangsung tanpa mengganggu kegiatan pembelajaran. Misalnya dengan : 1 (Belum
Berkembang), 2 (Mulai Berkembang), 3 ( Berkembang Sesuai Harapan), 4 ( Berkembang sangat Baik). Observasi yang dilakukan berkenaan dengan (a) Ketepatan anak memasukkan pakan ke dalam lungsi (b) Kerapian hasil anyaman (c) Kecepatan anak dalam menyelesaikan anyaman.

Tabel .1 Instrumen Observasi Kemampuan

\begin{tabular}{|c|c|c|c|c|c|}
\multicolumn{7}{c|}{ Motorik Halus } \\
\cline { 3 - 6 } No & $\begin{array}{c}\text { Aspek yang } \\
\text { diamati }\end{array}$ & \multicolumn{5}{|c|}{ Penilaian } \\
\cline { 3 - 6 } & & 1 & 2 & 3 & 4 \\
\hline 2 & $\begin{array}{c}\text { Ketepatan anak } \\
\text { memasukkan } \\
\text { pakan kedalam } \\
\text { lungsi }\end{array}$ & & & & \\
\hline 3 & $\begin{array}{c}\text { Kerapian hasil } \\
\text { anyaman }\end{array}$ & & & & \\
\hline & $\begin{array}{c}\text { Kecepatan anak } \\
\text { menyelasikan } \\
\text { anyaman }\end{array}$ & & & & \\
\hline
\end{tabular}

Keterangan :

1. BB : Belum Berkembang

2. MB : Masih berkembang

3. BSH : Berkembang Sesuai Harapan

4. BSB : Berkembang Sangat Baik

\section{Dokumentasi}

Dokumentasi dilakukan dengan cara mengambil foto siswa pada saat proses pembelajaran berlangsung. Foto tersebut berfungsi untuk merekam kegiatan penting yang dilakukan anak pada saat proses pembelajaran yang menggambarkan tentang partisipasi anak dalam kegiatan pembelajaran.

\section{Teknik Analisis Data}

Analisis data penelitian ada dua macam yaitu analisis deskriptif kuantitatif. Deskriptif kuantitatif untuk mengetahuipresentase kemampuan motorik halus anak dengan kegiatan 
menganyammenggunakan statistik. Dalam penelitian ini peneliti menggunakan analisis mengetahui tingkat keberhasilan dari penelitian ini menggunakan rumusrata-rata (mean). Rata-rata biasa dinotasikan dengan $\mathrm{X}$ adalah rata-rata dari keseluruhan nilai atau jumlah. Rata-rata dihitungdengan menjumlahkan semua data di bagi dengan jumlah datanya. Rumus yang dipakai adalah sebagai berikut :

$$
\mathrm{X}=\frac{\sum N}{\sum n} \mathrm{X} 100 \%
$$

Keterangan :

$\mathrm{N}$ : persentase ketuntasan belajar siswa

$\mathrm{X}$ : Jumlah siswa yang tuntas belajar

Y : Jumlah siswa keseluruhan (Anas

Sujiono : 2008:43)

Nilai ketuntasan kemampuan motorik halus anak adalah nilai anak dengan kategori berkembang sesuai harapan (BSH) dengan skor 3, dan berkembang sangat baik (BSB) dengan skor 4, yang menjadi indikator keberhasilan dalam peningkatan kemampuan motorik halus di kelompok A PAUD Az-zaitun.

\section{Indikator Keberhasilan}

Penelitian tindakan kelas ini dikatakan berhasil dengan baik apabila ada peningkatan keterampilan motorik halus anak di kelompok A PAUD Az-zaitun melalui kegiatan menganyam sedotan dengan nilai ketuntasan mencapai minimal
75\% dengang kategori baik. Sesuai dengan indikator keberhasilan tersebut, dapat disesuaikan pada tabel interval keberhasilan berikut ini :

Tabel .2 Tabel Nilai Rentang Persentase

Ketuntasan Penelitian

\begin{tabular}{|c|c|c|}
\hline No & $\begin{array}{c}\text { Rentang } \\
\text { Persentase }\end{array}$ & Kriteria Penilaian \\
\hline 1 & $80 \%-100 \%$ & Sangat Baik \\
\hline 2 & $61 \%-80 \%$ & Baik \\
\hline 3 & $41 \%-60 \%$ & Cukup \\
\hline 4 & $21 \%-40 \%$ & Kurang \\
\hline 5 & $0 \%-20 \%$ & Kurang sekali \\
\hline
\end{tabular}

\section{HASIL PENELITIAN DAN}

\section{PEMBAHASAN}

\section{Deskripsi Hasil Penelitian}

Pelaksanaan penelitian tindakan kelas dilakukan dalam 2 tahap yaitu siklus 1 dan siklus 2 dimana masing-masing siklus akan dilaksanakan dalam 3 kali pertemuan. Siklus 1 dilaksanakan pada tanggal 17-19 juli 2018 di PAUD Az-zaitun dengan tema diriku sub tema identitasku. Sedangkan siklus 2 dilaksanakan pada tanggal 23-25 juli 2018 dengan tema diriku dan sub tema identitasku. Adapun tahapan kegiatan siklus 1 meliputi perencanaan, pelaksanaan, observasi dan refleksi.

\section{Hasil pengamatan siklus 1}

Berdasarkan hasil pengamatan penelitian pada siklus 1 pada pertemuan 1 , 2 dan 3 menunjukkan bahwa adanya peningkatan keterampilan motorik halus anak meskipun belum signifikan, sehingga penelitian perlu dilanjutkan pada siklus berikutnya. Hal tersebut dikarenakan 
beberapa anak diantaranya terlihat kurang mampu dalam menganyam dan masih perlu dibantu oleh guru, sehingga pada siklus selanjutnya diharapkan anak sudah mahir dalam menganyam tanpa perlu dibantu oleh guru dan meningkatkan minat anak dalam menganyam dengan cara menambahkan variasi warna sedotan serta menganyam dengan motif lain.

Hasil pengamatan nilai ketuntasan penelitian pada siklus 1 pada pertemuan 1 , 2 dan 3 adalah sebesar $44 \%$ termasuk dalam kategori cukup yang akan diuraikan pada tabel berikut ini :

Tabel .3 Keterampilan Motorik Halus Anak Melalui Kegiatan Menganyam Siklus 1

\begin{tabular}{|c|c|c|c|c|c|}
\hline No & $\begin{array}{c}\text { Aspek } \\
\text { yang } \\
\text { dinilai } \\
\end{array}$ & $\begin{array}{l}\mathrm{P} \\
1\end{array}$ & $\begin{array}{l}P \\
2\end{array}$ & $\begin{array}{l}\mathrm{P} \\
3\end{array}$ & $\begin{array}{l}\text { Nilai } \\
\text { rata- } \\
\text { rata }\end{array}$ \\
\hline 1 & $\begin{array}{l}\text { Ketepatan } \\
\text { anak } \\
\text { dalam } \\
\text { memasuk } \\
\text { kan pakan } \\
\text { kedalam } \\
\text { lungsi }\end{array}$ & $\begin{array}{l}28 \\
\%\end{array}$ & $\begin{array}{l}42 \\
\%\end{array}$ & $\begin{array}{l}50 \\
\%\end{array}$ & $40 \%$ \\
\hline 2 & $\begin{array}{l}\text { kerapian } \\
\text { hasil } \\
\text { anyaman }\end{array}$ & $\begin{array}{l}21 \\
\%\end{array}$ & $\begin{array}{l}35 \\
\%\end{array}$ & $\begin{array}{l}42 \\
\%\end{array}$ & $32 \%$ \\
\hline 3 & $\begin{array}{l}\text { kecepatan } \\
\text { anak } \\
\text { dalam } \\
\text { menyelesa } \\
\text { ikan } \\
\text { anyaman }\end{array}$ & $\begin{array}{l}50 \\
\%\end{array}$ & $\begin{array}{l}50 \\
\%\end{array}$ & $\begin{array}{l}57 \\
\%\end{array}$ & $52 \%$ \\
\hline \multicolumn{2}{|c|}{$\begin{array}{l}\text { Nilai ketuntasan } \\
\text { siklus } 1\end{array}$} & \multicolumn{3}{|c|}{ Cukup } & $41 \%$ \\
\hline
\end{tabular}

Hasil pengamatan penelitian pada siklus 1 pada pertemuan 1,2 dan 3 digambarkan pada grafik sebagai berikut :

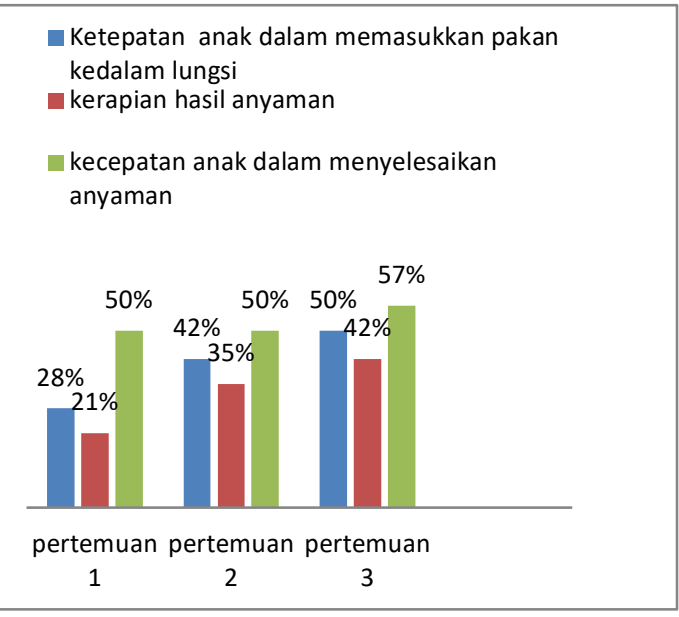

Gambar .2 Grafik Peningkatan

Keterampilan Motorik Halus Anak Siklus 1

Berdasarkan grafik hasil pengamatan siklus 1 diketahui bahwa keterampilan motorik halus anak melalui kegiatan menganyam pada anak kelompok A usia 45 tahun dinyatakan sudah mengalami peningkatan namun belum memenuhi nilai keberhasilan sehingga penelitian ini perlu dilanjutkan pada siklus berikutnya.

\section{Hasil pengamatan siklus 2}

Pada siklus 2 pertemuan ke 3, hasil pengamatan peningkatan keterampilan motorik halus anak dengan kategori berkembang sesuai harapan dan berkembang sangat baik, yaitu ketepatan anak dalam memasukkan pakan kedalam lungsi mencapai $85 \%$, kerapian hasil anyaman mencapai $85 \%$ dan kecepatan anak dalam menyelesaikan anyaman mencapai 92\%. Maka nilai ketuntasan keterampilan motorik halus anak melalui kegiatan menganyam siklus 2 pertemuan ke-3 sebesar $87 \%$. 
Tabel .4 Rekaptulasi Keterampilan Motorik Halus Anak Siklus 2

\begin{tabular}{|c|c|c|c|c|c|}
\hline $\begin{array}{l}\mathrm{N} \\
\mathrm{O}\end{array}$ & $\begin{array}{l}\text { Aspek yang } \\
\text { dinilai }\end{array}$ & $\begin{array}{l}\mathrm{P} \\
1\end{array}$ & $\begin{array}{l}\mathrm{P} \\
2\end{array}$ & $\begin{array}{l}\mathrm{P} \\
3\end{array}$ & $\begin{array}{l}\text { Nilai } \\
\text { rata- } \\
\text { rata }\end{array}$ \\
\hline 1 & $\begin{array}{c}\text { Ketepatan anak } \\
\text { dalam } \\
\text { memasukkan } \\
\text { pakan kedalam } \\
\text { lungsi }\end{array}$ & $\begin{array}{l}64 \\
\%\end{array}$ & $\begin{array}{l}78 \\
\%\end{array}$ & $\begin{array}{l}85 \\
\%\end{array}$ & $75 \%$ \\
\hline 2 & $\begin{array}{l}\text { Kerapian hasil } \\
\text { anyaman }\end{array}$ & $\begin{array}{l}71 \\
\%\end{array}$ & $\begin{array}{l}78 \\
\%\end{array}$ & $\begin{array}{l}85 \\
\%\end{array}$ & $78 \%$ \\
\hline 3 & $\begin{array}{c}\text { Kecepatan anak } \\
\text { dalam } \\
\text { menyelesaikan } \\
\text { anyaman }\end{array}$ & $\begin{array}{l}85 \\
\%\end{array}$ & $\begin{array}{l}85 \\
\%\end{array}$ & $\begin{array}{l}92 \\
\%\end{array}$ & $87 \%$ \\
\hline \multicolumn{2}{|c|}{$\begin{array}{c}\text { Nilai ketuntasan siklus } \\
2\end{array}$} & & & & $80 \%$ \\
\hline
\end{tabular}

Aspek penilaian dan proses pembelajaran siklus 2 sebagai berikut:

1. Peningkatan keterampilan motorik halus anak yaitu ketepatan anak dalam memasukkan pakan kedalam lungsi mencapai 75\%. Hal ini memujukkan bahwa keterampilan motorik halus anak melalui kegiatan menganyam dikategorikan sangat baik.

2. Peningkatan keterampilan motorik halus anak yaitu kerapian hasil anyaman mencapai 78 \%. Hal ini memujukkan bahwa keterampilan motorik halus anak melalui kegiatan menganyam dikategorikan sangat baik.

3. Peningkatan keterampilan motorik halus anak yaitu Kecepatan anak dalam menyelesaikan anyaman mencapai $87 \%$. Hal ini memujukkan bahwa keterampilan motorik halus anak melalui kegiatan menganyam dikategorikan sangat baik.

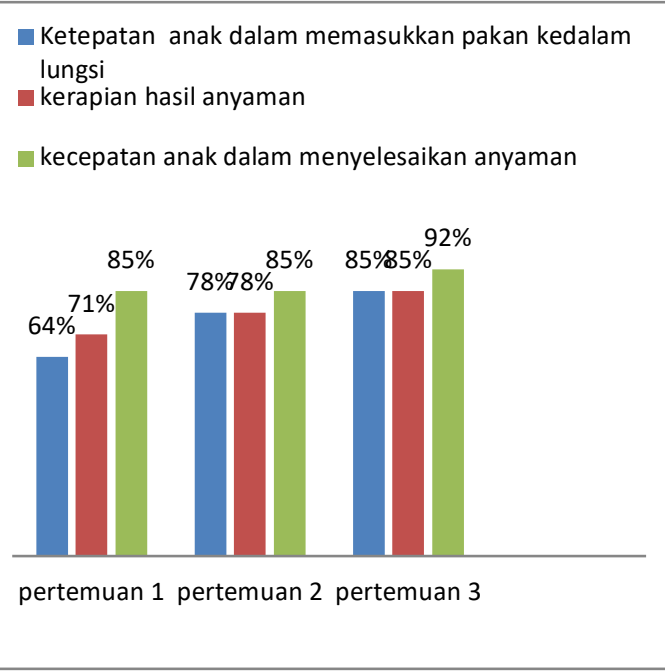

Grafik.3 Keterampilan Motorik Halus

Anak Siklus 2

Dari hasil penelitian mengenai keterampilan motorik halus anak melalui kegiatan menganyam diperoleh hasilnya pada siklus 2 nilai rata-rata yang diperoleh meningkat secara signifikan. Peningkatan keterampilan motorik halus anak anak melalui kegiatan menganyam antar siklus dapat dilihat pada grafik berikut ini :

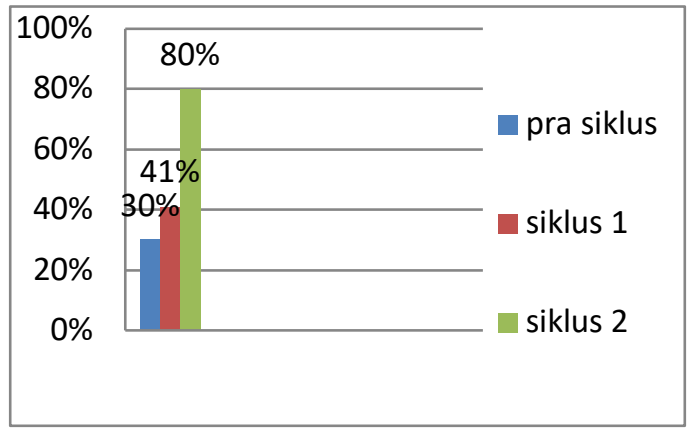

Grafik .4 Keterampilan Motorik Halus

Anak Antar Siklus

Dari hasil penelitian pengamatan keterampilan motorik halus anak melalui kegiatan menganyam terus meningkat hingga mencapai nilai ketuntasan sebesar $80 \%$ yang termasuk dalam kategori sangat 
baik. Peningkatan keterampilan motorik halus anak antar siklus dapat dilihat pada grafik berikut ini :

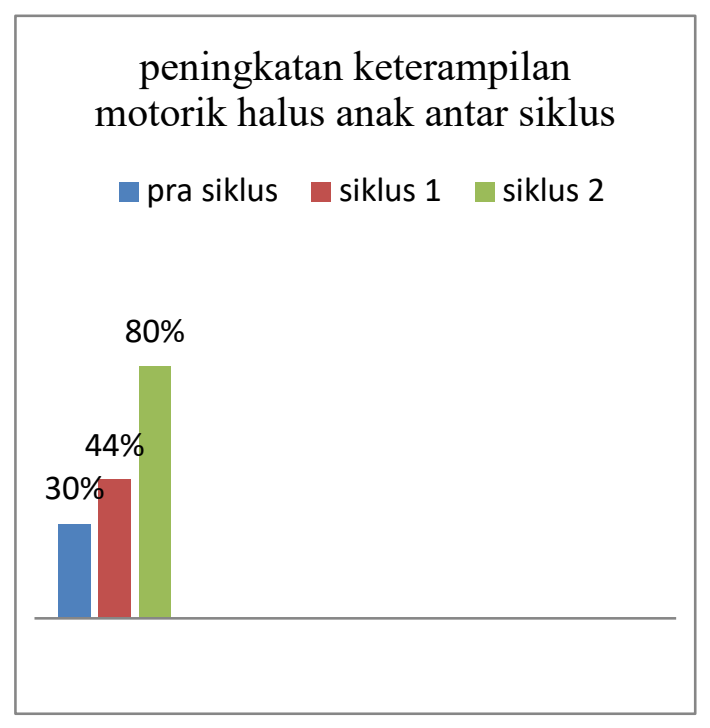

Grafik.5 Keterampilan Motorik Halus Anak

Antar Siklus

\section{Pembahasan Hasil Penelitian}

Berdasarkan pelaksanaan penelitian tindakan kelas (PTK) pada penelitian kali ini yang dilakukan sebanyak 2 siklus yaitu masing-masing siklus dilakukan sebanyak 3 kali pertemuan, diketahui hasilnya bahwa penelitian tindakan kelas ini berhasil karena dapat meningkatkan keterampilan motorik halus anak dengan angka pencapaian yaitu nilai rata-rata pada siklus ke-2 mencapai angka $80 \%$ dan berikut uraiannya :

1. Meningkatnya keterampilan motorik halus anak yaitu ketepatan anak memasukkan pakan kedalam lungsi pada siklus 1 mencapai nilai rata-rata $40 \%$ dan pada siklus 2 mencapai nilai rata-rata sebesar $75 \%$. Hal ini dikarenakan anak mampu mengerti dan mau mengikuti aturan yang diberikan oleh guru yaitu menganyam sesuai motif yang diinginkan serta jumlah pakan yang dimasukkan kedalam lungsi serta menuntut anak untuk berkonsentrasi penuh saat memasukkan pakan ke dalam lungsi.

2. Peningkatan keterampilan motorik halus anak yaitu kerapian hasil anyaman pada siklus 1 nilai rata-rata yang diperoleh sebesar $32 \%$ dan pada siklus ke-2 nilai rata-ratanya meningkat mencapai 78\%. Hal ini menujukkan bahwa anak semakin menguasai cara dan aturan dari menganyam, sehingga hasil anyaman terlihat lebih rapi.

3. Peningkatan keterampilan motorik halus anak yaitu kecepatan anak dalam menyelesaikan anyaman pada siklus 1 mencapai nilai rata-rata sebesar $52 \%$ kemudian pada siklus 2 meningkat hingga $87 \%$. Hal ini menunjukkan bahwa kecepatan anak dalam menganyam semakin meningkat seiring dengan meningkatnya keterampilan tangan yang melatih kelenturan jari-jemari dan koordinasi mata dengan tangan.

Kemampuan motorik halus anak dapat dikembangkan dengan berbagai cara, salah satunya yaitu dengan menganyam. Dengan menganyam dapat meningkatkan kemampuan motorik halus anak karena akan dapat melatih kelenturan jari-jemari anak, keterampilan tangan, dan koordinasi 
mata dan tangan serta dapat melatih konsentrasi anak dalam memasukkan pakan ke dalam lungsi. Selain itu, kegiatan menganyam dapat mengontrol emosi anak dimana anak sabar atau tidak memasukkan satu persatu pakan ke dalam lungsi, menganyam juga dapat membangkitkan minat belajar anak sehingga anak merasa antusias di dalam mengikuti pembelajaran. Oleh karena itu, peneliti tertarik untuk mengajarkan cara menganyam dalam penelitian ini, yang bertujuan untuk meningkatkan keterampilan motorik halus anak.

Berdasakan hasil penelitian tindakan kelas yang dilakukan selama 2 siklus yang terdiri dari 6 kali pertemuan, aspek keterampilan motorik halus yang diobservasi mengalami peningkatan yang baik dari kondisi awal sebelum diadakannya penelitian tindakan kelas hingga penelitian tindakan kelas siklus 2 tahap akhir. Pada siklus 1 dapat diperoleh hasil dengan nilai rata-rata 44\%, hal ini didapat dari hasil pengamatan keterampilan anak dengan metode pembelajaran yang masih dirasa baru oleh mereka sehingga mereka belum mampu terlalu menguasainya yaitu tata cara menganyam. Kemudian dilanjut pada siklus 2 keterampilan anak mengalami peningkatan dengan nilai ratarata sebesar $80 \%$, terjadi peningkatan karena pembelajaran sudah terlalu sering dilakukan oleh anak-anak dan bisa dikuasai oleh mereka serta lebih bervariasi dan menyenangkan. Hal tersebut membuktikan bahwa melalui kegiatan menganyam dapat meningkatkan keterampilan motorik halus pada anak usia 4-5 tahun di PAUD Azzaitun Genting Tanah

\section{KESIMPULAN}

Penelitian tindakan kelas ini menyimpulkan bahwa melalui kegiatan menganyam dapat meningkatkan keterampilan motorik halus anak pada anak kelompok A usia 4-5 tahun di PAUD Azzaitun genting Tanah tahun pembelajaran 2018/2019. Hal ini ditandai oleh peningkatan persentase hasil belajar, yaitu sebagai berikut :

1. Peningkatan keterampilan motorik halus anak pada kondisi prasiklus yaitu kemampuan anak memasukkan pakan kedalam lungsi sebesar 21\%, kerapian hasil anyaman sebesar $28 \%$ dan kecepatan menyelesaikan anyaman sebesar $42 \%$.

2. Peningkatan keterampilan motorik halus anak pada siklus 1 yaitu nilai rata-rata kemampuan anak memasukkan pakan kedalam lungsi sebesar $40 \%$, kerapian hasil anyaman sebesar $32 \%$ dan kecepatan menyelesaikan anyaman sebesar 52\%.

3. Peningkatan keterampilan motorik halus anak pada siklus 2 yaitu nilai rata-rata kemampuan anak memasukkan pakan kedalam lungsi sebesar $75 \%$, kerapian hasil anyaman 
sebesar $\quad 78 \%$ dan kecepatan menyelesaikan anyaman sebesar $87 \%$.

Sehingga dapat disimpulkan bahwa peningkatan keterampilan motorik halus anak pada usia 4-5 tahun di PAUD Azzaitun Genting Tanah tahun pembelajaran2018/12019 dapat ditingkatkan melalui kegiatan menganyam dengan nilai ketuntasan $80 \%$ yang termasuk sangat baik.

\section{DAFTAR PUSTAKA}

Arikunto, 2106. Penelitian Tindakan Kelas. Jakarta : Bumi Aksara

Augusta. 2012. Pengertian Anak Usia Dini. Diakses dari http://infoini.com/pengertian/anak/usia/dini pada tanggal 23 januari 2018

Bambang, Sujiono. 2005. Metode Pengembangan Fisik. Jakarta: Universitas Terbuka.

Hajar et al. 2008. Seni Keterampilan Anak. Jakarta: Universitas Terbuka.

Maria, J. Wantah. 2005. Pengembangan Disiplin dan Pembentukan Moral Pada Anak Usia Dini. Jakarta: Depdiknas.

Martha, Christianti. TT. Bab IV Menganyam Untuk Anak Usia Dini. Diakses dari : http://staff.uny.ac.id/si /penelitian/MarthaChristianti,\%20 Pada tanggal 20 Januari 2018, Pukul 08.08 WIB.

Hidayah, Nur. 2016. Peningkatan Kemampuan Motorik Halus Melalui Kegiatan Menganyam pada Anak Kelompok A2 Di TK PKK 30 Mulyorini,Surobayan Agromulyo Sedayu Bantul.

Diakses

dari http://eprints.uny.ac.id/15445/1/SKRIP SI.pdf pada tanggal 21 januari 2018 pukul 12.00 WIB Peraturan Menteri
Pendidikan Nasional nomor 58 Tahun 2009

Purwanto 2011. Statistika Untuk Penelitian. Yogyakarta: Pustaka Pelajar.

Slamet, Suyanto. 2005. Dasar - Dasar Pendidikan Anak Usia Dini. Yogyakarta : Hikayat Publish

Sukamti, Rini Endang. 2007. Diktat Perkembangan Motorik. Yogyakarta: FIK Universitas Negeri Yogyakarta.

Sumantri, 2005. Model Pengembangan Keterampilan Motorik Anak Usia Dini. Jakarta: Departemen Pendidikan Nasional.

Ningsih, U. Ninik. 2017. Peningkatan Keterampilan Motorik Halus Anak Melalui Kegiatan Menganyam Dengan Berbagai Media pada Kelompok A2 TK Sultan Agung Ngaglik. Diakses dari http://www.ejurnal.com $/ 2015 / 06 /$ peningkatankemampuan-motorik-halus $12 . \mathrm{html}$ pada tanggal 20 Januari 2018.

Suwarsih, Madya. 2007. Teori dan Praktik Penelitian Tindakan Kelas. Bandung: Alfabeta.

Undang -undang Nomor 23 Tahun 2003 tentang Sistem Pendidikan Nasional

Wina, Sanjaya. 2009. Penelitian Tindakan Kelas. Jakarta: Kencana.

Widya, Universitas and Gama Mahakam. 2017. "MENINGKATKAN KEMAMPUAN MOTORIK HALUS ANAK USIA 5-6 TAHUN MELALUI KEGIATAN KOLASE DENGAN BAHAN BULU AYAM DI TK TUNAS HARAPAN." 1624. 